\title{
A mio-inozitol jótékony hatása inzulint igénylő 2-es típusú cukorbetegséghez társuló polycystás ovarium szindrómás várandós terápiájában
}

\author{
Kun Attila dr. ${ }^{1}$ - Tornóczky János dr. ${ }^{2}$ \\ Tolna Megyei Balassa János Kórház, 'Szülészet-Nőgyógyászat Osztály, \\ ${ }^{2}$ Megyei Diabétesz Gondozó, Szekszárd
}

\begin{abstract}
A szerzők a mio-inozitol hatását mutatják be egy 2-es típusú diabetes mellitusban szenvedő, inzulinkezelést is igénylö, egyben polycystás ovarium szindrómás (PCOS) várandósnál. A betegnek korábban inzulinkezelés és metformin adása mellett sem volt egyensúlyban a szénhidrátháztartása, hypoglykaemiás rosszullétei gyakoriak voltak. Mio-inozitol és folsav étrendkiegészítő-adás megkezdésével szénhidrátháztartása javult, két hónap múlva várandós lett. A várandósság 19. terhességi hetében inkomplett vetélése zajlott. A magzat kórboncolása során a patológus nem talált fejlődési rendellenességet. E terápia mellett a beteg később újból várandós lett, és 29 hetesen egy koraszülöttnek adott életet. Az esetbemutatás arra kívánja felhívni a figyelmet, hogy a mio-inozitol-tartalmú étrend-kiegészítő hatékonyabbá teheti a cukorbetegség kezelését. Orv. Hetil., 2017, 158(14), 541-545.
\end{abstract}

Kulcsszavak: inzulint igénylő 2-es típusú cukorbetegség, polycystás ovarium szindróma, várandósság

\section{The myo-inositol is beneficial in the therapy of pregnancy with insulin- dependent type 2 diabetes and polycystic ovary syndrome}

\begin{abstract}
Authors would like to demonstrate the beneficial effect of myo-inositol supplementation in a pregnant woman with insulin-dependent type 2 diabetes mellitus and polycystic ovary syndrome. Insulin and metformin treatment could not achieve normalization of glucose homeostasis for 3 years, and hypoglycemic episodes were frequent. Myo-inositol and folic acid supplementation added to the basic treatment resulted in improved glucose levels in 2 months. At this time she became pregnant. During pregnancy serum glucose levels still improved in the next 2 months. The amniotic membrane ruptured at the 19th gestational week, and pregnancy had to be finished. Developmental disturbances were excluded by the pathologist. She became pregnant again and gave birth to a premature male neonate at the 29th gestational week. The aim of the report was to demonstrate that myo-inositol supplementation may improve the efficacy of the therapy in type 2 diabetes mellitus.
\end{abstract}

Keywords: insulin-dependent type 2 diabetes, polycystic ovary syndrome, pregnancy

Kun, A., Tornóczky, J. [The myo-inositol is beneficial in the therapy of pregnancy with insulin-dependent type 2 diabetes and polycystic ovary syndrome]. Orv. Hetil., 2017, 158(14), 541-545.

(Beérkezett: 2016. augusztus 10.; elfogadva: 2017. február 12.)

\section{Rövidítések}

$\mathrm{BMI}=($ body mass index $)$ testtömegindex $; \mathrm{FSH}=$ folliculusstimuláló hormon; GADA = glutaminsav-dekarboxiláz-ellenes antitest; GDM = (gestational diabetes mellitus) terhességi cukorbetegség; IAA = inzulin-autoantitestek, ICA = (islet cell antibodies) szigetsejtellenes antitestek; LADA = (latent auto- immun diabetes in adults) latens felnőttkori autoimmun diabetes mellitus; LH = luteinizáló hormon; PCOS = (polycystic ovar syndrome $)$ polycystás ovarium szindróma; $\mathrm{SHGB}=(\operatorname{sex}$ hormone-binding globulin) nemihormon-kötő szérumfehérje; $\mathrm{TSH}=$ (thyroid-stimulating hormone) pajzsmirigymúködést serkentő hormon 
Az inzulinrezisztencia intracelluláris mechanizmusa pontosan még nem ismert diabetes mellitusban, terhességi cukorbetegségben (gestatiós diabetes mellitus - GDM), illetve polycystás ovarium szindrómában (PCOS). Az inozitol egy hat szénatomos ciklusos polialkoholos foszfoglikán molekula, amelynek kilenc különböző izomerje van. Bizonyítást nyert, hogy közülük a legnagyobb mennyiségben a B-vitamin-komplex részéhez tartozó mio-inozitol fordul elő a természetben és az egészséges emberi szervezetben is. A mio-inozitol az ember foszfolipidjeiben található, és fokozza a lecitin endogén termelődését. Ezenkívül még szerepet játszik a zsír- és szénhidrát-anyagcserében, mivel a glükóz metabolizmusát szabályozó enzimeket aktiválja. Normális táplálkozás során gyümölcsök, zöldségek, főzelékek, hüvelyesek és diófélék fogyasztásával fedezzük a napi szükségletet. Az átlagos étrend körülbelül 0,9 g mio-inozitolt tartalmaz. Ha a napi szükséglet szintje nő (például: PCOS, GDM), vagy a sejtekben alacsony a koncentrációja, az hozzájárulhat az inzulinrezisztencia létrejöttéhez [1-7]. Ezekben az esetekben a mio-inozitol pótlása javíthatja az inzulinérzékenységet [8].

Esetünk ismertetésével azt szeretnénk bemutatni, hogy a mio-inozitol miként befolyásolja a korábbi, inzulinadást is igénylő kezelést 2-es típusú diabetes mellitusban és polycystás ovarium szindrómában is szenvedő várandósnál.

\section{Esetismertetés}

A 27 éves nóbetegnek 2011 óta volt ismert és kezelt cukorbetegsége. A kórisme felállításakor nem volt lehetőség autoantitestek vizsgálatára (szigetsejtellenes antitest [ICA], inzulin-autoantitest [IAA], glutamin-dekarboxiláz-ellenes antitest [GADA]) intézményünkben. LADA mellett szólt a tünetszegénység, a polyuria, a polydipsia, valamint a testsúlycsökkenés hiánya. A beteg alkalmassági vizsgálata során glucosuriát észleltek a vizeletben. További vizsgálat során $19,7 \mathrm{mmol} / 1$ vércukorszintet, valamint $118 \mathrm{mmol} / \mathrm{mol}(12,9 \%) \mathrm{HbA}_{\mathrm{lc}}{ }^{-t}$ találtak. Kivizsgálása során l-es típusú cukorbetegséget feltételeztek a magas vércukor-, $\mathrm{HbA}_{\mathrm{lc}}$-szint és a cukorbetegség irányában negatív családi anamnézis alapján, amelyet megerősíteni vélt a beteg fiatal életkora. Rövid hatású (13-8-9 E), valamint hosszú hatású (este 12 E) humán inzulin-, valamint $1 \times 1000 \mathrm{mg}$ metforminkezelést kezdtek. Az éhomi szérum-C-peptid szintjének meghatározására csak egy év múlva volt lehetőség (1,98 ng/ml), ami szintén LADA mellett szólt. A betegnél a közlemény megírása közben elvégzett vizsgálatok - ICA: negatív, GADA: negatív, IAA emelkedett $(1,8 \mathrm{U} / \mathrm{ml}$ [referenciaérték: $0,0-0,4]$ ), de az utóbbi teszt nem tud különbséget tenni az endogén és exogén inzulin elleni antitest között - alapján inzulinkezelést is igénylő 2-es típusú diabetes mellitus kórisméjét lehetett felállítani. Korábban nem volt várandós. A ki-kimaradó és gyenge menstruációs vérzései mellett fokozottabb szőrnövekedést is lehetett észlelni. Az endokrin kivizsgálása során a szérumprolaktin- (136,9 mIU/l) és -TSH szintje $(1,961$ $\mu \mathrm{IU} / \mathrm{ml}$ ) normális tartományban voltak. A laborvizsgálatoknál a szérumtesztoszteron-szint $(3,35 \mathrm{nmol} / \mathrm{l}) \mathrm{ma}-$ gas, és a menstruációs ciklusa 21 . napján meghatározott szérumprogeszteron-szint nagyon alacsony $(1,2 \mathrm{ng} / \mathrm{ml})$ értéket mutatott, az utóbbiak viszont PCOS-re utaltak. A PCOS-re jellemző LH/FSH eltolódás nem volt észlelhető (LH: 5,63 IU/1, FSH: 6,49 IU/1). Ultrahangvizsgálat nagyobb, PCOS-re jellegzetes petefészkeket írt le $(5,5 \mathrm{~cm}$-es homogén szerkezetú uterusban $0,4 \mathrm{~cm}$-es endometrium, a jobb oldalon 4,0 $\times 2,8 \mathrm{~cm}-\mathrm{es}$, a bal oldalon $3,3 \times 2,5$ cm-es nagyságú ovariumok voltak, mindegyikben 9-12 darab, 0,5-0,8 cm-es, körkörösen elhelyezkedő kis folliculusokkal). A beteg a kórisme felállításakor diétás oktatásban részesült. Felhívtuk a figyelmét a mozgásterápia fontosságára, ezért mindennapjai részévé vált a séta, a kerékpározás és a kertészkedés is. A gondozás során már ekkor említést tettünk a magas vércukorértékek kedvezőtlen hatásáról várandósság esetén, így javasoltuk a fogamzásgátlást is, amit alkalmazott. A cukorbetegségének felismerése után két évvel a romló szénhidrátháztartás kezelésére már ultragyors hatású inzulinanalógot (Novorapid, 18-18-18 E) és este 54 E elhúzódó hatású bázis inzulinanalógot (Lantus), valamint $1 \times 1000 \mathrm{mg}$ metformint (Mercformin XR) alkalmaztunk. A terápia mellett nem sikerült az ideális, normoglykaemiás állapotot elérni, a $\mathrm{HbA}_{\mathrm{lc}} 77 \mathrm{mmol} / \mathrm{mol}$ (9,2\%-os) szintje is jelezte az elégtelen szénhidrátháztartást. Ha a $\mathrm{HbA}_{\mathrm{lc}}$ értéke 75-86 mmol/mol (9-10\%) közötti, akkor a súlyos magzati malformációk aránya a $20 \%$-ot is elérheti [9]. A beteg a terhesség elleni védekezési hiba miatt 2013-ban várandós lett. A rossz anyagcserehelyzet mellett öthetesen missed abortus következett be. Ekkor a beteg testsúlya $97 \mathrm{~kg}$ volt. Az eredménytelen várandóssága után már szeretett volna gyermeket. Szénhidrátháztartása a diéta tartása és az életmód-változtatás ellenére sem javult. Többször vizsgáltuk ultrahanggal a tüszőérését. Ezek alkalmával ritkán észleltünk tüszőrepedést, még ovulációindukció során sem. Továbbra is előfordultak az egy-két hónapos vérzéskimaradások. Ezen próbálkozások után saját kérésére - a kórházunk etikai bizottságának jóváhagyásával - az eddigi terápia mellé 2014 márciusában elkezdtünk egy étrend-kiegészítő készítményt (2 g mio-inozitol és 0,2 mg folsav [Inofolic]) alkalmazni $2 \times 1$ adagban. Már két hónap múlva az inzulinadagolás kisfokú módosítása (1515-15 E Novorapid, valamint este 60 E Lantus) és 1000 mg metformin mellett az éhomi vércukorszint $6,1-7,3$ mmol/l-re, illetve az étkezés utáni vércukor-koncentráció 9,0-10,4 mmol/1-re csökkent. Fogamzáskor azonban még alacsonyabb értékekre szükséges törekedni. Az a legideálisabb, ha a $\mathrm{HbA}_{\mathrm{lc}} 35-45 \mathrm{mmol} / \mathrm{mol}(5,3-$ $6,3 \%)$, a vércukorérték esetében az éhomiak: 3,5-5,5 mmol/1 és az étkezés utániak 5,0-8,0 mmol/1 közöttiek [9]. A vércukorszintek ilyen mértékű csökkenése mellett egy másik jelentős pozitív eredmény is bekövetkezett: 
a közérzete javult, a hirtelen vércukoresés miatt létrejövő rosszullétek megszűntek, az édesség utáni vágya csökkent, és a vérzéskimaradások elmaradtak. Ezen étrendkiegészítő két hónapos alkalmazása mellett öthetes várandósság került felismerésre, a $\mathrm{HbA}_{\mathrm{lc}}$ értéke $69 \mathrm{mmol} /$ mol-ra $(8,5 \%)$ csökkent. A beteg a malformációkra való felvilágosítás után végül a várandósság megtartása mellett döntött. Fokozott gondozás során többször volt genetikai és magzati ultrahangvizsgálaton, amelyek negatív eredményekkel zárultak. Két hónappal később e terápia további alkalmazásával a vércukorértékek még tovább javultak (éhomi vércukorértékek: 4,8-5,3 mmol/l, míg az étkezés utáni vércukorszintek: 7,0-8,2 mmol/l voltak). Ezek a vércukorértékek már terhesség alatti jó egyensúlyi helyzetet jeleztek, és a $\mathrm{HbA}_{\mathrm{lc}}$ értéke $53 \mathrm{mmol} / \mathrm{mol}$-ra $(7,0 \%)$ csökkent. A testsúlya az étrend-kiegészító alkalmazása előttihez képest $4 \mathrm{~kg}$-mal kevesebb lett. Több laborparamétere is kedvezó irányba változott (1. táblá$z a t)$. Ez a jó egyensúlyi helyzet a várandósság második trimeszterében is megmaradt, ugyanakkor a 19. héten elfolyt a magzatvíz, és így a várandósságot be kellett fejezni. A magzat kórboncolása során a patológus nem talált fejlődési rendellenességet.

\section{Megbeszélés}

A PCOS első közlése 1935-ben Stein és Levental nevéhez füződik [10]. A kórképre elhízás, oligoamenorrhoea, meddőség, fokozott szőrnövekedés és megnagyobbodott, sima, szürkés felszínú petefészkek jellemzőek. Az ovariumok megvastagodott tunika albiguniája alatt gyöngyfüzérszerúen 5-9 mm-es elzáródott tüszők találhatók. Ez a leggyakoribb endokrin kórkép, a nók 5-10\%ában fordul elő attól függően, hogy milyen kritériumrendszert alkalmazunk. A betegség pontos etiológiája nem ismert. A genetikai és az intrauterin környezetnek a szerepe meghatározó lehet ennek a komplex endokrin metabolikus betegségnek kialakulásában [11].

A PCOS kialakulásában a hypothalamus-hypophysismellékvese tengely, illetve az ovariumok is szerepet játszanak. Ennek következtében nő az LH- (luteinizáló hormon) szekréció és megváltozhat az LH/FSH (folliculusstimuláló hormon) arány. Az LH a theca-sejtekben serkenti az androgéntermelést is, amelynek következtében több folliculus érésnek indul, azonban fejlődésük során megrekednek és elmarad a domináns folliculus kiválasztódása [12]. A betegek felében nem mutatható ki LH-szint-emelkedés [11], ahogyan a mi betegünknél is láthattuk. A PCOS-hez különböző anyagcserezavarok (károsodott glükóztolerancia vagy 2 -es típusú diabetes mellitus és elhízás), valamint szövődmények (szív- és érszövődmények) társulnak az évek folyamán [13]. A PCOS kérdésében 2013-2014-ben két nagy nemzetközi ajánlás született. Az egyik az amerikai, az Endocrine Society (úgynevezett ENDO) állásfoglalása [11], a másik az európai, a European Society of Endocrinology (ESE) irányelve [12]. Az ENDO-irányelv a rotterdami
1. táblázat |Alapjellemzők alakulása mio-inozitol terápia előtt és után

\begin{tabular}{lll}
\hline & $\begin{array}{l}\text { Mio-inozitol } \\
\text { terápia előtt } \\
\text { közvetlenül }\end{array}$ & $\begin{array}{l}\text { Mio-inozitol } \\
\text { terápia után } \\
\text { négy hónappal }\end{array}$ \\
\hline $\begin{array}{l}\text { Önellenórzés során: } \\
\text { Átlag éhomi vércukor }\end{array}$ & $10,1-12,2 \mathrm{mmol} / 1$ & $4,8-5,3 \mathrm{mmol} / 1$ \\
$\begin{array}{l}\text { Átlag étkezés utáni } \\
\text { vércukor }\end{array}$ & $10,4-12,1 \mathrm{mmol} / 1$ & $7,0-8,2 \mathrm{mmol} / 1$ \\
Laboratóriumi: & & \\
Éhomi vércukor & $10,2 \mathrm{mmol} / 1$ & $5,3 \mathrm{mmol} / 1$ \\
Éhomi C-peptid & $1,98 \mathrm{ng} / \mathrm{ml}$ & $1,43 \mathrm{ng} / \mathrm{ml}$ \\
HbgA ${ }_{l c}$ & $77 \mathrm{mmol} / \mathrm{mol}$ & $53 \mathrm{mmol} / \mathrm{mol}$ \\
& $(9,2 \%)$ & $(7,0 \%)$ \\
Összkoleszterin & $6,6 \mathrm{mmol} / 1$ & $5,5 \mathrm{mmol} / 1$ \\
HDL-koleszterin & $1,85 \mathrm{mmol} / 1$ & $1,60 \mathrm{mmol} / 1$ \\
LDL-koleszterin & $3,54 \mathrm{mmol} / 1$ & $3,23 \mathrm{mmol} / 1$ \\
Triglicerid & $2,75 \mathrm{mmol} / 1$ & $1,55 \mathrm{mmol} / 1$ \\
Testsúly & $97 \mathrm{~kg}$ & $93 \mathrm{~kg}$ \\
Testmagasság & $173 \mathrm{~cm}$ & $173 \mathrm{~cm}$ \\
BMI & 32,4 & 31,1 \\
Derékbőség & $102 \mathrm{~cm}$ & $99 \mathrm{~cm}$ \\
Csípóbő́ség & $115 \mathrm{~cm}$ & $110 \mathrm{~cm}$ \\
Derék-csípó arány & 0,89 & 0,90 \\
Terápia Novorapid & $18-18-18 \mathrm{E}$ & $15-15-15 \mathrm{E}$ \\
$\quad$ Lantus (este) & $54 \mathrm{E}$ & $60 \mathrm{E}$ \\
$\quad$ Merkformin XR & $1000 \mathrm{mg}$ & $1000 \mathrm{mg}$ \\
\hline & & \\
& &
\end{tabular}

2003-as szempontokat veszi figyelembe [14], amely szerint a PCOS három fó kritériuma közül (1.: oligomenorrhoea, anovulációs ciklusok; $2 .:$ hyperandrogenia vagy klinikai hyperandrogenismus; $3 .:$ ultrahanggal a megnagyobbodott petefészkekben minimum 10 darab, $1 \mathrm{~cm}$-nél kisebb subscapularis tüsző látható), ha legalább kettő jelen van, akkor fel lehet állítani a diagnózist. Ehhez azonban az alábbi endokrinológiai megbetegedések kizárása is elengedhetetlen: hypothyreosis, androgéntermelő daganatok, felnőttkori adrenalis hyperplasia és hyperprolactinaemia. (Az ESE esetében az ENDO-kritériumon kívül még az androgéntúlsúly kórisme is alapfeltétel.) Az endokrinológiai kivizsgálás során a betegünknél mind a három fő kritériumot megtaláltuk, és a többi betegséget is kizártuk.

A PCOS-betegek többsége túlsúlyos. A testsúlycsökkentés diétával és testmozgással (fizikai gyakorlás 30 percig naponta) egyaránt kedvezően befolyásolja a kórképet. Minimális, akár $5-15 \%$-os fogyás is csökkenti a hyperandrogenismus tüneteit és hozzájárulhat a menstruációs ciklus rendeződéséhez [15]. Az irodalmi adatok és klinikai tapasztalok szerint metformin adása a nők felénél rendezheti a ciklust. Második vonalbeli szerként alkalmazható, ha antikoncipiens kontraindikált vagy a beteg nem akar fogamzásgátlót szedni, illetve, ha szén- 
hidrátanyagcsere-zavar is fennáll. PCOS-ben a metformin csak „off label”, engedéllyel alkalmazható Magyarországon. A tudományos kutatások azt mutatják, hogy az inozitol jótékonyan hat az ovulációra és csökkenti az androgéntermelést PCOS-ben, csökken a szérum tesztoszteronszintje és növekszik a nemihormon-kötő globulin (sex hormone-binding globulin - SHBG) koncentrációja, sôt még az inzulinszekréció is csökken. Ezen változások mellett az is bizonyított, hogy inozitolpótlás során már kisebb FSH-szint mellett is kialakul a peteérés, és javul az oocyták minősége. Nagyobb számú oocyta gyưjthető petefészek-stimulációt követően mesterséges megtermékenyítés során $[16,17]$. Egy átfogó német tanulmányban összehasonlították a mio-inozitol és a metforminkezelés eredményességét PCOS-es meddő nők körében. A szerzők megállapították, hogy a mio-inozitol klinikai hatásossága hasonló a metforminéhoz, ugyanakkor biztonságos, és a betegek jobban tolerálják, mint a másik kezelést [18]. A legújabb hipotézis szerint a mioinozitol képes javítani az inzulinrezisztenciát. Metabolikus hatása is kedvező, mert csökkenti az LDL-koleszterin- és trigliceridszintet, illetve a HDL-koleszterin-szintet növeli [8]. Az utóbbi egy-két évben több prospektív tanulmány leírta, hogy a GDM gyakorisága csökken PCOS-es, illetve cukorbetegség irányában pozitív családi anamnézisû várandósok esetében, ha a gondozás alatt mio-inozitol étrend-kiegészítésben részesültek [19, 20]. 25-30 kg/m² közötti anyai BMI esetén 27,4\%-ról $11,6 \%$-ra, $30 \mathrm{~kg} / \mathrm{m}^{2}$ feletti anyai BMI esetén 33,6\%-ról 14,0\%-ra csökken a GDM előfordulása, ha az első trimesztertől a szülésig alkalmazták a mio-inozitol étrendkiegészítőt [21, 22]. Megállapították, hogy mio-inozitol alkalmazásával az anyáknál csökkent az inzulinigény, és az anyák késóbbi terhességi hétben szültek. A született magzatok adatait elemezve azt észlelték, hogy a készítmény alkalmazásakor az újszülötteknél a macrosomia, valamint a születés utáni hypoglykaemia ritkább volt [23].

Esetünk sikertelen várandósságának hátterében a teherbe esés idejekor fennálló rossz anyagcserehelyzet valószínüsíthető. Mio-inozitollal kiegészített terápia mellett több hónapos, terhesség elleni védekezés után az első nem védekezéses ciklusban újra várandós lett. Ekkor a $\mathrm{HbA}_{\mathrm{lc}}$ szintje $53 \mathrm{mmol} / \mathrm{mol}(7,0 \%)$ volt. Végig jó vércukorértéket észleltünk. A 29. hétben leállíthatatlanul beindult a koraszülés, és per vias naturales módon 1900 grammos fiúgyermek született (Apgar 7/8). Születése óta szépen fejlődik, és a korához képest semmilyen téren visszamaradást nem mutattak ki. Azért nem az utóbbi sikeresen végződő várandósságát írtuk le, mert a mioinotizol szénhidrátháztartásra kifejtett kedvező hatását a részletesen szemléltetett eset mutatta. A kiegészítő kezelést a korábbi sikertelen várandóssága előtt két hónappal kezdtük el. A kórházunk etikai bizottságának jóváhagyásával, a nemzetközi szakirodalom tapasztalatai alapján [8, 19-23], azoknál a terhességi cukorbetegeknél, akiknél a megfelelő diéta mellett néhány egység inzulin adását kellett volna elkezdeni, ott a várandós írásos beleegyezését követóen felajánlottuk a diéta és az inzulinkezelés alternatív lehetőségeként a diéta melletti mioinozitol alkalmazását is. Ezekben az esetekben is végig fokozott diabetológiai kontrollt alkalmaztunk. Amenynyiben ezzel a kezeléssel nem tudjuk tartani a Magyar Diabetes Társaság által felállított terápiás célértékeket, a későbbiekben a diéta mellett inzulinra állunk át. A súlyosabbnak ítélt GDM-ben a diéta mellett már eleve inzulint kezdünk el.

\section{Következtetések}

Esetünk kapcsán arra a következtetésre jutottunk, hogy diabetesben a mio-inozitol kiegészítő kezelés javíthatja a megkezdett terápia hatásosságát a szénhidrát-anyagcserére, és kedvező hatású lehet a teherbe esésre. Több más laboratóriumi értékben is kedvező változást észlelhetünk az alkalmazása során.

Anyagi támogatás: A közlemény megírása anyagi támogatásban nem részesült.

Szerzôi munkamegosztás: K. A.: Az adatok gyújtése, a kézirat megszövegezése. T. J.: A belgyógyászati rész megszövegezése, a kézirat revíziója. A cikk végleges változatát a szerzők elolvasták és jóváhagyták.

Érdekeltségek: A szerzőknek nincsenek érdekeltségeik.

\section{Irodalom}

[1] Buchanan, T. A., Xiang, A. H.: Gestational diabetes mellitus. J. Clin. Invest., 2005, 115(3), 485-491.

[2] Suzuki, S., Kawasaki, H., Satoh, Y.: Urinary chiro-inositol excretion is an index marker of insulin sensitivity in Japanese type II diabetes. Diabetes Care, 1994, 17(12), 1465-1468.

[3] Scioscia, M., Kunjara, S., Gumaa, K., et al.: Urinary excretion of inositol phosphoglycan P-type in gestational diabetes mellitus. Diabet. Med., 2007, 24(11), 1300-1304.

[4] Baillargeon, J. P., Diamanti-Kandarakis, E., Ostlund, R. E. Jr., et al.: Altered D-chiro-inositol urinary clearance in women with polycystic ovary syndrome. Diabetes Care, 2006, 29(2), 300305.

[5] Nestler, J. E., Jakubowicz, D. J., Reamer, P., et al.: Ovulatory and metabolic effects of D-chiro-inositol in the polycystic ovary syndrome. N. Engl. J. Med., 1999, 340(17), 1314-1320.

[6] Genazzani, A. D., Lanzoni, C., Ricchieri, F., et al.: Myo-inositol administration positively affects hyperinsulinemia and hormonal parameters in overweight patients with polysystic ovary syndrome. Gynecol. Endocrinol., 2008, 24(3), 139-144.

[7] Chin, T. T., Rogers, M. S., Briton-Jones, C., et al.: Effects of myoinositol on the in vitro maturation and subsequent development of mouse oocytes. Hum. Reprod., 2003, 18(2), 408-416.

[8] Corrado, F., D'Anna, R., Di Vieste, G., et al.: The effect of myoinositol supplementation on insulin resistance in patients with gestational diabetes. Diabet. Med., 2011, 28(8), 972-975.

[9] Baranyi, É.: Pregestaional diabetes mellitus: preconception care. [Praegestatiós diabetes: prekoncepcionális gondozás.] Diab. Hung., 2013, 21(S2), 18-24. [Hungarian] 
[10] Stein, I. F., Levental, M. L.: Amenorrhoea assiated with bilateral polycysic ovaries. Am. J. Obstet. Gynecol., 1935, 29(2), 181191

[11] Legro, R. S., Arslanian, S. A., Ehrmann, D. A., et al.: Diagnosis and treatment of polycystic ovary syndrome: an Endocrine Society clinical practice guideline. J. Clin. Endocrinol. Metab, 2013, 98(12), 4565-4592.

[12] Conway, G., Dewailly, D., Diamanti-Kandarakis, E., et al.: The polycystic ovary syndrome: a position statement from the European Society of Endocrinology. Eur. J. Endocrinol., 2014, $171(4), \mathrm{P} 1-\mathrm{P} 29$.

[13] Ehrmann, D. A.: Polycystic ovary syndrome. N. Engl. J. Med., 2005, 352(12), 1223-1236.

[14] The Rottendam ESHRE/ASRM-Sponsored PCOS Consensus Workshop Group: Revised 2003 consensus on diagnostic criteria and long term health risk related to polycystic ovary syndrome. Fertil. Steril., 2004, 81(1), 19-25.

[15] Hollmann, M., Runnebaum, B., Gerbard, I.: Effects of weight loss on the hormonal profile in obese, infertile women. Hum. Reprod., 1996, 11(9), 1884-1891.

[16] Gerli, S., Papaleo, E., Ferrari, A., et al:: Randomized, double blind placebo controlled trial: effects of Myo-inozitol on ovarian function and metabolic factors in women with PCOS. Eur. Rev. Med. Pharmacol. Sci., 2007, 11(5), 347-354.

[17] Ciotta, L., Stracquadanio, M., Pagano, I., et al.: Effects of myoinositol supplementation on oocyte's quality in PCOS patients: a double blind trial. Eur. Rev. Med. Pharmacol. Sci., 2011, 15(5), 509-514.
[18] Regidor, P. A., Schindler, A. E.: Myoinositol as a safe and alterna tive approach in the treatment of infertile PCOS women: A German observational study. Internat. J. Endocrinol., 2016, (2016), 9537632. doi.org/10.1155/2016/9537632

[19] D'Anna, R., Di Benedetto, V., Rizzo, P., et al.: Myo-inositol may prevent gestational diabetes in PCOS women. Gynecol. Endocrinol., 2012, 28(6), 440-442.

[20] D'Anna, R., Scilipoti, A., Giordano, D., et al.: Myo-inositol supplementation and onset of gestational diabetes mellitus in pregnant women with a family history of type 2 diabetes: a prospec tive, randomized, placebo-controlled study. Diabetes Care, 2013, 36(4), 854-857.

[21] D'Anna, R., Di Benedetto, A., Scilipoti, A., et al.: Myo-inozitol supplementation for prevention of gestational diabetes in obese pregnant women: A randomized controlled trial. Obstet. Gynecol., 2015, 126(2), 310-315.

[22] Santamaria, A., Di Benedetto, A., Petrella, E., et al.: Myo-inozitol may prevent gestational diabetes onset in overweight women: randomized, controlled trial. J. Matern. Fetal Neonatal Med., 2016, 29(19), 3234-3237.

[23] Matarrelli, B., Vitacolonna, E., D'Angelo, M., et al.: Effect of dietary myo-inositol supplementation in pregnancy on the incidence of maternal gestational diabetes mellitus and fetal outcomes: a randomized controlled trial. J. Matern. Fetal Neonatal Med., 2013, 26(10), 967-972.

(Kun Attila dr., Szekszárd, Béri B. Á. u. 5-7., 7100 e-mail: dr.kun.attila@gmail.com)

\title{
Hepatológia Nap - Székesfehérvár
}

\author{
Hepatológia - múlt, jelen és jövő \\ Időpont: 2017. április 7. \\ Helyszín: Hiemer Rendezvényközpont, Hiemer-ház, \\ Székesfehérvár, Oskola u. 2-4.
}

\section{Elözetes program}

10:00-10:10 Megnyitó

Dr. Cser-Palkovics András, Székesfehérvár polgármestere

Dr. Csernavölgyi István a Fejér megyei Szent György Egyetem Oktató Kórház főigazgatója

Üléselnök: Gógl Árpád, Csomós Géza

10:10-10:40 Meinhardt Classen: A 35-year perspective on liver diseases - past and future

10:40-11:10 Gervain Judit: Székesfehérvári Hepatológia Centrum - kezdetektől napjainkig

11:10-11:20 Izbéki Ferenc: Lokális cselekvés és globális gondolkodás a hepato-gasztroenterológiában

11:30-12:00 Kávészünet

12:00-12:20 Schaff Zsuzsa: 35 év a hepato-patológiában

12:20-12:40 Szalay Ferenc: Hepatológiai újdonságok és aktualitások Magyarországon 2017-ben

12:40-13:00 Pár Alajos: A 21. század új pandémiája a NASH

13:00-13:20 Hunyady Béla: Quo vadis Hepatologia?

13:30

Konferenciazárás, ebéd 